\title{
PENGARUH OPINI AUDIT TAHUN SEBELUMNYA, KUALITAS AUDITOR, KINERJA KEUANGAN TERHADAP PEMBERIAN OPINI AUDIT GOING CONCERN (STUDI EMPIRIS PADA PERUSAHAAN MANUFAKTUR YANG TERDAFTAR DI BEI PERIODE 2012-2016)
}

\author{
Nia Tresnawaty \\ Fakultas Ekonomi, Universitas Satya Negara Indonesia, Jakarta \\ E-mail : niatresna@yahoo.com
}

\begin{abstract}
ABSTRAK
Penelitian ini bertujuan untuk mengetahui pengaruh opini audit tahun sebelumnya, kualitas auditor, kinerja keuangan terhadap pemberian opini audit going concern.

Populasi penelitian ini adalah perusahaan manufaktur yang terdaftar di Bursa Efek Indonesia (BEI) pada tahun 2012-2016 yaitu sebanyak 143 perusahaan. Sampel penelitian berjumlah 32 perusahaan atau 160 data observasi yang dipilih dengan metode purposive sampling. Data yang dipergunakan adalah data sekunder yang diperoleh dari Bursa Efek Indonesia (BEI) dan analisis data menggunakan analisis Regresi Logistik. Hasil penelitian membuktikan opini audit tahun sebelumnya berpengaruh positif dan signifikan terhadap opini going concern, sedangkan kualitas auditor, kinerja keuangan tidak berpengaruh terhadap opini going concern. Hasil dari penelitian ini menunjukkan bahwa secara simultan opini audit tahun sebelumnya, kualitas auditor, kinerja keuangan terhadap pemberian opini audit going concern adalah berpengaruh.
\end{abstract}

Kata Kunci : Opini Audit Going Concern, Opini Audit Tahun Sebelumnya, Kualitas Auditor, Kinerja Keuangan.

\section{ABSTRACT}

This study aims to determine the effect of previous audit opinion, the quality of auditors, financial performance to the provision of going concern audit opinion.

The population of this study is a manufacturing company listed on the Indonesia Stock Exchange (BEI) in 2012-2016 as many as 143 companies. The sample of research is 32 companies or 160 observation data selected by purposive sampling method. The data used are secondary data obtained from Indonesia Stock Exchange (IDX) and data analysis using logistic regression analysis. The result of the research proves that the audit opinion of previous year has positive and significant effect to the going concern opinion, while the quality of auditor, financial performance does not affec to going concern opinion. The result of this research shows that simultaneously the previous year audit opinion, auditor quality, financial performance toward giving going concern audit opinion is influential

Keywords: Going Concern Audit Opinion, Audit Opinion of the previous year, Auditor Quality, Financial Performance. 


\section{PENDAHULUAN}

Setiap perusahaan pasti akan melaporkan dan menerbitkan laporan keuangan sebagai bentuk pertanggungjawaban kepada pihak-pihak yang berkepentingan. Sesuai dengan PSAK No. 1 Tahun 2012, tujuan dari laporan keuangan adalah memberikan informasi mengenai posisi keuangan, kinerja, dan arus kas dari suatu entitas yang diharapkan dapat bermanfaat bagi pengguna laporan keuangan dalam membuat keputusan ekonomi, sehingga keandalan laporan keuangan ini menjadi sangat penting. Kebutuhan akan keandalan laporan keuangan inilah yang mendorong dibutuhkannya jasa pihak ketiga yaitu auditor independen untuk memberi jaminan bahwa laporan keuangan yang disajikan manajemen perusahaan dapat dipercaya sebagai dasar keputusan-keputusan yang diambil oleh mereka. Berdasarkan teori agensi yang mengasumsikan bahwa manusia itu selalu self interest, maka kehadiran pihak ketiga yang independen sebagai mediator pada hubungan antara prinsipal dan agen sangat diperlukan, dalam hal ini adalah auditor independen. Namun, masalah yang sering dihadapi oleh auditor dalam memberikan opini audit going concern adalah sangat sulit untuk memprediksi kelangsungan hidup suatu perusahaan. Apabila auditor memberikan opini audit going concern, maka perusahaan akan menjadi lebih cepat bangkrut karena banyak investor yang membatalkan investasinya atau kreditor yang menarik dananya (Sasmita, Yuniarta dan Darmawan, 2015). Opini audit going concern yang diberikan oleh auditor akan sangat berdampak pada perusahaan, salah satu dampak yang dirasakan dari opini audit going concern bagi perusahaan adalah semakin berkurangnya jumlah investasi ke perusaahaan yang menyebabkan kegiatan produksi perusahaan menjadi tersendat dan berujung pada tidak maksimalnya pada laba yang dihasilkan perusahaan di tiap tahunnya.

Penelitian Soliyah (2014) serta Nur dan Herry (2013) berpendapat bahwa opini audit tahun sebelumnya berpengaruh terhadap pemberian opini audit going concern. Sedangkan hasil penelitian Aiisiah dan Pamudji (2012) menyimpulkan bahwa opini audit tahun sebelumnya tidak berpengaruh terhadap opini audit going concern. Penelitian yang dilakukan oleh Friska (2015) menyatakan bahwa likuiditas berpegaruh terhadap pemberian opini going concern. Sedangkan penelitian Noverio (2011) menyatakan bahwa likuiditas tidak berpengaruh terhadap pemberian opini going concern. Penelitian Noverio (2011) menyimpulkan bahwa kualitas auditor, profitabilitas dan solvabilitas berpengaruh terhadap pemberian opini audit going concern. Sedangkan Nur dan Herry (2013) berpendapat bahwa kualitas auditor, profitabilitas dan likuiditas tidak berpengaruh terhadap pemberian opini audit going concern.

Dalam penelitian ini peneliti mengambil objek pada perusahaan manufaktur, dikarenakan masih sedikitnya dari peneliti terdahulu yang menggunakan objek tertentu serta transaksi perusahaan manufaktur lebih besar, lebih kompleks dan lebih bervariasi dibanding dengan sektor lainnya. Sehingga peneliti tertarik untuk menggunakan perusahaan tersebut sebagai objek penelitian ini.

\section{LANDASAN TEORI}

\section{Teori Agensi (Agency Theory)}

Menurut Jensen dan Meckling (1976) dalam Januarti (2007) teori agensi adalah Teori yang melihat bahwa adanya kontrak antara prinsipal (pemegang saham) dengan agen (manajer) sebagai suatu hubungan keagenan (agency relationship). Hubungan antara principal dengan agen yaitu principal sebagai pihak yang memberikan wewenang dan mengevaluasi kinerja dari agen, dan agen sebagai pihak yang mengelola perusahaan dan mengambil 
keputusan atas nama pemegang saham. Teori agensi juga berkaitan dengan utility maximizers dimana terdapat kesempatan yang lebih besar untuk setiap pihak dalam memaksimalkan kepentingan sendiri.

Teori keagenan (agency theory) menjelaskan adanya konflik antara manajemen selaku agen dengan pemilik selaku principal. Principal ingin mengetahui segala informasi termasuk aktivitas manajemen, yang tekait dengan meminta laporan pertanggungjawaban pada agen (manajemen). Berdasarkan laporan tersebut principal menilai kinerja manajemen. Tetapi yang acapkali terjadi adalah kecenderungan manajemen untuk melakukan tindakan yang membuat laporannya kelihatan baik, sehingga kinerjanya dianggap baik. Untuk mengurangi atau meminimalkan kecurangan yang dilakukan oleh manajemen dan membuat laporan keuangan yang dibuat manajemen lebih reliable (dapat dipecaya) dipergunakan pengujian. Pengujian ini dilakukan oleh pihak yang independen, yaitu auditor independen.

\section{Laporan Keuangan}

Menurut Ani Rahmaniar, SE, MMSI. dan Soegijanto, SE., MM. (2016:107) laporan keuangan adalah hasil dari proses akuntansi yang menggambarkan kondisi dan posisi keuangan serta hasil usaha suatu perusahaan pada periode tertentu. Pendapat lain dikemukakan oleh Kasmir (2015:7), yang menyatakan bahwa laporan keuangan adalah laporan yang menunjukkan kondisi keuangan perusahaan pada saat ini atau satu periode tertentu.

\section{Audit}

Dalam ASOBAC (A Statement of Basic Auditing Concepts) audit adalah :

Audit merupakan suatu proses sistematis untuk menghimpun asersi-asersi tentang berbagai tindakan dan kejadian ekonomi untuk menentukan tingkat kesesuaian antara asersi-asersi tersebut dengan kriteria yang telah ditentukan dan menyampaikan hasilnya kepada para pemakai yang berkepentingan.

Sedangkan menurut Sukrisno (2012:4), auditing adalah Suatu pemeriksaan yang dilakukan secara kritis dan sistematis, oleh pihak yang independen, terhadap laporan keuangan yang telah disusun oleh manajemen, beserta catatan-catatan pembukuan dan buktibukti pendukungnya, dengan tujuan untuk dapat memberikan pendapat mengenai kewajaran laporan keuangan tersebut.

Menurut Alvin A. Arens, Mark S. Beasley dan Randal J. Elder (2011:4) dalam buku Sukrisno Agoes (2012:3), audit adalah Proses pengumpulan dan pengevaluasian bahan bukti tentang informasi yang dapat diukur mengenai suatu entitas ekonomi yang dilakukan oleh seorang kompeten dan independen untuk dapat menentukan dan melaporkan kesesuaian informasi dimaksud dengan kriteria-kriteria yang telah ditetapkan.

\section{Opini Audit}

Menurut Standar Profesional Akuntan Publik (SPAP) per 31 Maret 2011 (PSA 29 SA Seksi 508), ada lima jenis pendapat atau opini yang dikeluarkan oleh auditor, yaitu :

1. Pendapat Wajar Tanpa Pengecualian (Unqualified Opinion). Dengan pendapat wajar tanpa pengecualian, auditor menyatakan bahwa laporan keuangan menyajikan secara wajar, dalam semua hal yang material, posisi keuangan, hasil usaha, perubahan ekuitas, dan arus kas suatu entitas sesuai dengan SAK/ETAP/IFRS.

2. Pendapat Wajar Tanpa Pengecualian Dengan Bahasa Penjelas (Unqualified Opinion With Explanatory Language). Pendapat ini diberikan jika terdapat keadaan tertentu yang mengharuskan auditor menambahkan paragraf penjelasan (atau bahasa penjelasan lain) 
dalam laporan audit, meskipun tidak memengaruhi pendapat wajar tanpa pengecualian yang dinyatakan oleh auditor.

3. Pendapat Wajar Dengan Pengecualian (Qualified Opinion) Pendapat wajar dengan pengecualian menyatakan bahwa laporan keuangan dinyatakan secara wajar, dalam semua hal yang material, posisi keuangan, hasil usaha, perubahan ekuitas, dan arus kas sesuai dengan SAK/ETAP/IFRS, kecuali untuk dampak hal yang berkaitan dengan yang dikecualikan.

4. Pendapat Tidak Wajar (Adverse Opinion). Pendapat ini dinyatakan bila menurut pertimbangan auditor laporan keuangan secara keseluruhan tidak disajikan secara wajar sesuai dengan SAK/ETAP/IFRS. Apabila auditor menyatakan pendapat tidak wajar, auditor harus menjelaskan dalam paragraf terpisah sebelum paragraf pendapat dalam laporannya.

5. Tidak Memberikan Pendapat (Disclaimer op Opinion). Auditor dapat tidak menyatakan suatu pendapat bilamana auditor tidak dapat merumuskan atau tidak merumuskan suatu pendapat tentang kewajaran laporan keuangan sesuai dengan SAK/ETAP/IFRS.

\section{Opini Audit Going Concern}

Opini audit modifikasi mengenai going concern merupakan opini audit yang dalam pertimbangan auditor terdapat ketidakmampuan atau ketidakpastian signifikan atas kelangsungan hidup perusahaan dalam menjalankan operasinya pada kurun waktu yang pantas, tidak lebih dari satu tahun sejak tanggal laporan keuangan yang sedang diaudit (SPAP, 2011). Going concern dipakai sebagai asumsi dalam pelaporan keuangan sepanjang tidak terbukti adanya informasi yang menunjukan hal berlawanan (contrary information).

Standar Profesional Akuntan Publik (SPAP) seksi 341 (IAI, 2011), memberikan pedoman kepada auditor tentang dampak kemampuan satuan usaha dalam mempertahankan kelangsungan hidupnya terhadap opini auditor sebagai berikut:

1. Jika auditor yakin bahwa terdapat kesangsian mengenai kemampuan satuan usaha dalam mempertahankan kelangsungan hidupnya dalam jangka waktu pantas, ia harus:

a. Memperoleh informasi mengenai rencana manajemen yang ditujukan untuk mengurangi dampak kondisi dan peristiwa tersebut.

b. Menetapkan kemungkinan bahwa rencana tersebut secara efektif dilaksanakan.

2. Jika manajemen memiliki rencana tersebut, langkah selanjutnya yang harus dilakukan oleh auditor adalah menyimpulkan efektivitas rencana tersebut.

a. Jika auditor berkesimpulan rencana tersebut tidak efektif, auditor menyatakan tidak memberikan pendapat.

b. Jika auditor berkesimpulan rencana tersebut efektif dan klien mengungkapkan secara memadai, maka auditor akan memberikan pendapat wajar tanpa pengecualian dengan paragraf penjelas mengenai kemampuan satuan usaha dalam mempertahankan kelangsungan hidupnya.

c. Jika auditor berkesimpulan rencana tersebut efektif akan tetapi klien tidak mengungkapkan secara memadai, maka auditor memberikan pendapat wajar dengan pengecualian atau pendapat tidak wajar.

\section{Opini Audit Tahun Sebelumnya}

Opini audit tahun sebelumnya adalah opini audit yang diterima oleh perusahaan pada tahun sebelumnya atau 1 tahun sebelum penelitian. Opini audit ini dibedakan menjadi dua yaitu opini audit going concern dan opini audit non going concern. Perusahaan yang telah menerima opini audit going concern pada tahun sebelumnya dianggap memiliki masalah 
dalam mempertahankan kelangsungan hidupnya, sehingga kemungkinan besar auditor akan memberikan opini audit going concern kembali pada tahun berjalan (Santosa dan Wedari, 2007 dalam Soliyah 2014).

\section{Kualitas Auditor}

DeAngelo (1981) dalam Herry dan Nur (2013) menyatakan bahwa auditor skala besar memiliki insentif lebih untuk menghindari kritikan kerusakan reputasi dibandingkan pada auditor skala kecil. Auditor skala besar lebih cenderung untuk mengungkapkan masalahmasalah yang ada karena mereka lebih kuat menghadapi resiko proses peradilan. Argumen tersebut berarti bahwa auditor skala besar memiliki insentif lebih untuk mendeteksi dan melaporkan masalah going concern kliennya. Penelitian ini akan membagi ukuran kantor akuntan publik berdasarkan adanya ikatan atau berafiliasi dengan kantor akuntan publik internasional, yaitu kantor akuntan publik Big Four dengan kantor akuntan publik Non Big Four. Kantor akuntan publik Big Four adalah sebagai berikut:

1. KAP yang berafiliasi dengan Price Waterhouse Coopers (PWC).

2. KAP yang berafiliasi dengan Delloite Touche Tohmatsu

3. KAP yang berafiliasi dengan Ernest and Young (EY)

4. KAP yang berafiliasi dengan Klynveld Peat Marwick Goerdeler (KPMG)

\section{Kinerja Keuangan}

Menurut IAI (2007) Kinerja Keuangan adalah kemampuan perusahaan dalam mengelola dan mengendalikan sumberdaya yang dimilikinya. Pengukuran kinerja digunakan perusahaan untuk melakukan perbaikan diatas kegiatan operasionalnya agar dapat bersaing dengan perusahaan lain. Analisis kinerja keuangan merupakan proses pengkajian secara kritis terhadap review data, menghitung, mengukur, menginterprestasi, dan memberi solusi terhadap keuangan perusahaan pada suatu periode tertentu. Kinerja Keuangan dapat dinilai dengan beberapa alat analisis, salah satunya dalah menggunakan analisis rasio keuangan. Analisis Rasio Keuangan, merupakan teknik analisis keuangan untuk mengetahui hubungan di antara pos tertentu dalam neraca maupun laporan laba rugi baik secara individu maupun secara simultan. Menurut Jumingan (2006:242) "Analisis Rasio Keuangan merupakan analisis dengan membandingkan satu pos laporan dengan dengan pos laporan keuangan lainnya, baik secara individu maupun bersama-sama guna mengetahui hubungan diantara pos tertentu, baik dalam neraca maupun dalam laporan laba rugi”.

\section{Profitabilitas}

Profitabilitas adalah kemampuan perusahaan memperoleh laba dalam hubungannya dengan penjualan, total aktiva, maupun modal sendiri. Profitabilitas diproksikan dengan Return on Asset (ROA). Return on assets (ROA) menunjukkan kemampuan perusahaan menghasilkan laba dari aset yang dipergunakan. Menurut Kasmir (2015:156)“ Return On asset merupakan rasio yang menunjukkan hasil (Return) atas jumlah aktiva yang digunakan dalam perusahaan. Menurut Harahap (2010:305), rasio ini menunjukkan berapa besar laba bersih diperoleh perusahaan bila diukur dari nilai aset. Return On Assets (ROA) dapat dihitung dengan menggunakan rumus sebagai berikut:

$$
\boldsymbol{R O A}=\frac{\text { LabaBersih }}{\text { Total Asset }} \times 100 \%
$$




\section{Likuiditas}

Rasio likuidias menunjukkan kemampuan perusahaan dalam melunasi kewajiban jangka pendeknya. Menurut Hery (2015:175) rasio likuiditas adalah rasio yang dapat digunakan untuk mengukur sampai seberapa jauh tingkat kemampuan perusahaan dalam melunasi kewajiban jangka pendeknya pada saat jatuh tempo. Sementara itu menurut Sutrisno (2009) dalam Dwi Sariningsih dan Ardi Paminto (2012), mendefinisikan likuiditas adalah kemampuan perusahaan untuk membayar kewajiban-kewajibannya yang segera harus dipenuhi. Ukuran rasio likuiditas terdiri dari tiga alat ukur, yaitu Current Ratio, Quick Ratio atau Acid Test Ratio dan Cash Ratio. Alat ukur likuiditas yang digunakan dalam penelitian ini adalah Current Ratio. Rasio ini menunjukkan sejauh mana aset lancar dengan utang lancar menutupi kewajiban-kewajiban lancar. Semakin besar perbandingan aset lancar dengan utang lancar semakin tinggi kemampuan perusahaan menutupi kewajiban jangka pendeknya yang diukur dengan rumus :

$$
\text { Current Ratio }=\frac{\text { Assat Innmar }}{\text { Kewajiban Lancar }} \times 100 \%
$$

\section{Solvabilitas}

Rasio solvabilitas digunakan untuk mengukur kemampuan perusahaan untuk memenuhi seluruh kewajibannya, baik jangka pendek maupun jangka panjang apabila perusahaan dibubarkan (dilikuidasi). Menurut Dr. Kasmir (2015:151) rasio solvabilitas merupakan rasio yang digunakan untuk mengukur sejauh mana aktiva perusahaan dibiaya dengan utang. Apabila rasionya tinggi, yang artinya pendanaan dengan utang semakin banyak, maka semkain sulit bagi perusahaan untuk memperoleh tambahan pinjaman karena dikhawatirkan perusahaan tidak mampu menutupi utang-utangnya dengan aktiva yang dimilikinya.

Demikian pula jika rasionya rendah, maka semakin kecil perusahaan dibiayai dengan utang. Rumus untuk mencari debt ratio dapat digunakan sebagai berikut:

$$
\text { TDTA Ratio }=\frac{\text { Total biabilities }}{\text { Total Asset }} \times 100 \%
$$

\section{METODE PENELITIAN}

\section{Populasi dan Sample}

Penelitian ini menggunakan populasi berupa Perusahaan manufaktur yang terdaftar di Bursa Efek Indonesia (BEI) tahun 2012 sampai dengan 2016. Sample penelitian ini adalah purposive sampling dimana sample dipilih berdasarkan karakteristik anggota sample yang disesuaikan dengan maksud penelitian. Dalam penelitian ini kriteria yang digunakan adalah:

1. Perusahaan manufaktur yang terdaftar di BEI periode 2012-2016.

2. Perusahaan Manufaktur yang menerbitkan laporan keuangan lengkap untuk periode 2012-2016, telah mengirimkan laporan keuangan pada pusat referensi pasar modal Indonesia dan dipublikasikan di www.idx.co.id.

3. Perusahaan manufaktur yang konsisten melampirkan laporan auditor independen atas laporan keuangan yang telah diaudit pada tahun 2012-2016.

4. Perusahaan manufaktur yang mengalami rugi minimal 2 kali dalam periode penilitian, yaitu pada tahun 2012-2016. Hal ini dikarenakan auditor hampir tidak pernah mengeluarkan opini audit going concern pada perusahaan yang memiliki laba bersih setelah pajak yang positif (McKeown, dkk 1991 dikutip oleh Santoso dan Wedari, 2007) 


\section{Jenis Data}

Data yang digunakan dalam penelitian ini adalah data sekunder. Data sekunder meliputi laporan keuangan perusahaan yang dimuat dalam publikasi Indonesian Capital Market Directory (ICMD) yang terdaftar di BEI. Sumber data yang digunakan untuk menghitung variabel dalam penelitian ini adalah perusahaan manufaktur yang diperoleh di Bursa Efek Indonesia periode 2012-2016.

\section{Desain Penelitian}

Desain yang digunakan dalam penelitian ini adalah penelitian kausal. Penelitian kausal ini merupakan penelitian yang dilakukan untuk menguji hipotesis tentang pengaruh antara satu atau lebih variabel bebas terhadap variabel terikat, dalam hal ini adalah Pengaruh Opini Audit Tahun Sebelumnya, Kualitas Auditor, Profitabilitas, Likuiditas, dan Solvabilitas terhadap pemberian Opini Audit Going Concern.

\section{Hipotesis}

Pengujian hipotesis bertujuan untuk mengetahui pengaruh opini audit tahun sebelumnya, kualitas audit, profitabilitas, likuiditas, dan solvabilitas terhadap pemberian opini audit going concern. Adapun hipotesis yang akan diuji adalah sebagai berikut :

$\mathrm{H}_{01}$ : Tidak ada pengaruh opini audit tahun sebelumnya terhadap opini audit going concern.

$\mathrm{H}_{\mathrm{a} 1}$ : Ada pengaruh opini audit tahun sebelumnya terhadap opini audit going concern.

$\mathrm{H}_{02}$ : Tidak ada pengaruh kualitas audit terhadap opini audit going concern.

$\mathrm{H}_{\mathrm{a} 2}$ : Ada pengaruh kualitas audit terhadap opini audit going concern.

$\mathrm{H}_{03}$ : Tidak ada pengaruh profitabilitas terhadap opini audit going concern.

$\mathrm{H}_{\mathrm{a} 3}$ : Ada pengaruh profitabilitas terhadap opini audit going concern.

$\mathrm{H}_{04}$ : Tidak ada pengaruh likuiditas terhadap opini audit going concern.

$\mathrm{H}_{\mathrm{a} 4}$ : Ada pengaruh likuiditas terhadap opini audit going concern.

$\mathrm{H}_{05}$ : Tidak ada pengaruh solvabilitas terhadap opini audit going concern.

$\mathrm{H}_{\mathrm{a} 5}$ : Ada pengaruh solvabilitas terhadap opini audit going concern.

$\mathrm{H}_{06}$ : Tidak ada pengaruh opini audit tahun sebelumnya, kualitas audit, profitabilitas, likuiditas, dan solvabilitas terhadap opini audit going concern.

$\mathrm{H}_{\mathrm{a} 6}$ : Ada pengaruh opini audit tahun sebelumnya, kualitas audit, profitabilitas, likuiditas, dan solvabilitas terhadap opini audit going concern.

\section{Kerangka Pemikiran}

Kerangka berfikir merupakan model konseptual tentang bagaimana teori berhubungandengan berbagai faktor yang telah diidentifikasi sebagai hal yang penting. Adapun kerangka pemikiran dalam penelitian ini dapat digambarkan dalam sebuah gambar sebagai berikut : 


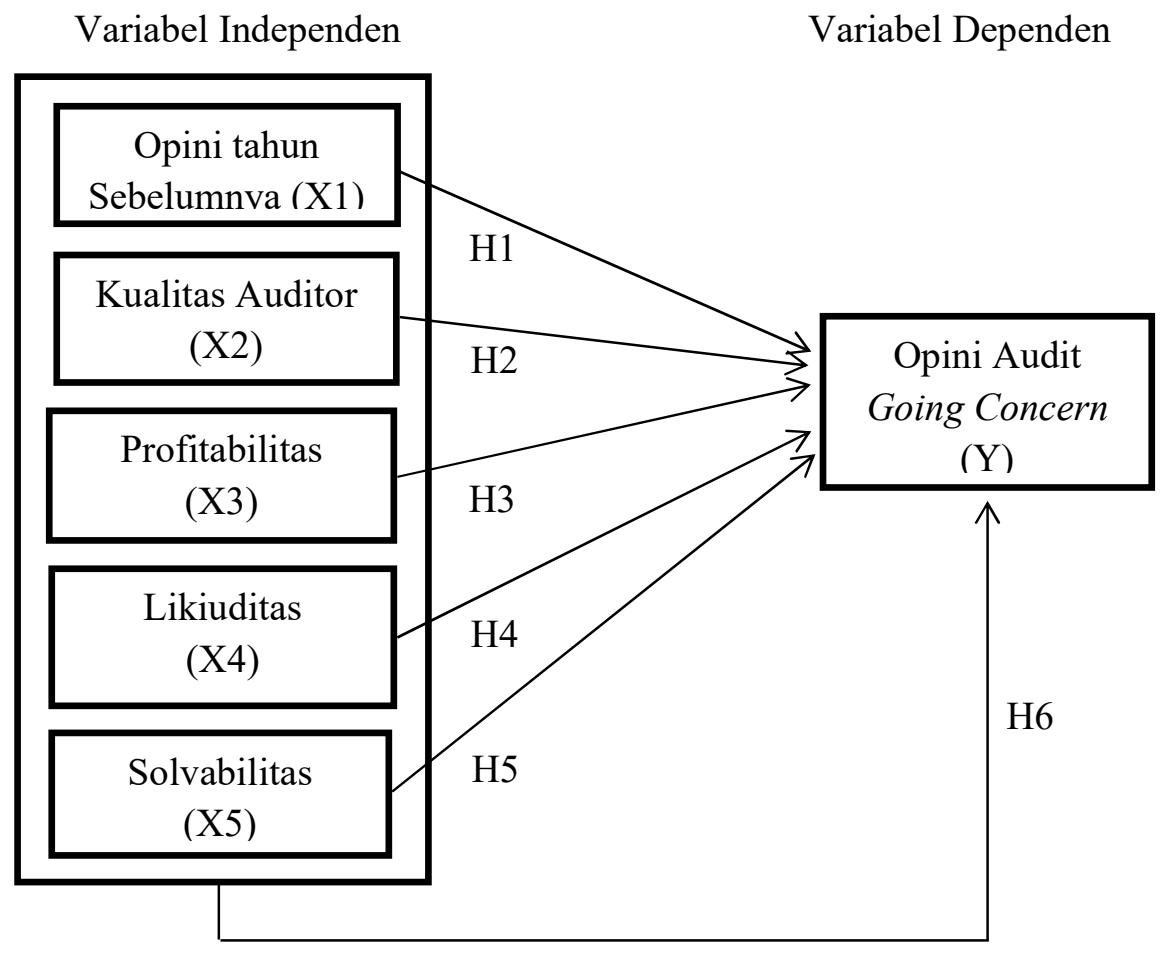

\section{Gambar \\ Kerangka Pemikiran}

\section{Variabel dan Skala Pengukuran}

\section{Variabel Dependen (Variabel Y)}

Dalam penelitian ini yang menjadi variabel dependen adalah Pemberian Opini Audit Going Concern. Variabel pemberian opini audit going concern diukur dengan menggunakan variabel dummy. Kategori 1 untuk perusahaan manufaktur yang menerima opini audit going concern dan 0 untuk perusahaan manufaktur yang menerima opini audit non going concern.

\section{Variabel Independen (Variabel X)}

Variabel independen yang digunakan dalam penelitian ini adalah sebagai berikut:

\section{a. Opini Tahun Sebelumnya (X1)}

Jika ditahun sebelumnya perusahaan menerima Opini audit going concern (GCAO) maka diberi kode 1, sedangkan jika ditahun sebelumnya menerima opini audit non going concern (NGCAO) diberi kode 0 .

b. Kualitas Auditor (X2)

Jika KAP termasuk kategori Big Four, maka diberi kode 1, sedangkan KAP Non Big Four diberi kode 0 . 


\section{c. Profitabilitas (X3)}

Rasio profitabilitas diproksikan dalam rasio Retrun on Asset (ROA). Rasio ini dinyatakan dalam bentuk persentase $(\%)$ dan rumus yang digunakan adalah:

$$
\mathrm{ROA}=\frac{\text { Laba Bersih }}{\text { Total Asset }} \times 100 \%
$$

\section{d. Likuiditas (X4)}

Rasio Likuiditas diproksikan dengan Current Ratio atau rasio lancar yang merupakan ukuran tingkat keamanan terhadap ketidakpastian dan kejutan atas arus kas perubahan. Current ratio dirumuskan sebagai berikut:

$$
\text { Current Ratio }=\frac{\text { Asset Lancar }}{\text { Kewajiban Lancar }} \times 100 \%
$$

\section{e. Solvabilitas (X5)}

Solvabilitas pada penelitian ini diproksikan dengan debt to total asset ratio. Untuk memenuhi kebutuhan dananya perusahaan bisa menggunakan modal sendiri atau modal yang berasal dari pemilik, dan bisa juga berasal dari pinjaman atau hutang.

$$
\text { TDTA Ratio }=\frac{\text { Total Liabilities }}{\text { Total Asset }} \times 100 \%
$$

\section{Metode Pengumpulan Data}

Metode Analisis Data

Analisis Statistik Deskriptif

Variabel-variabel dalam penelitian ini dideskriptifkan dengan menggunakan statistik deskriptif.

\section{Pengujian Model dan Hipotesis Penelitian}

Pada penelitian ini pengujian model dan hipotesis dilakukan dengan menggunakan regresi logistik (logistic regression). Variabel dependen dalam penelitian ini adalah opini audit going concern yang dinyatakan dengan varaiabel dummy. Dimana perusahaan yang mendapat opini audit going concern diberi kode 1 dan untuk perusahaan yang mendapat opini non going concern diberi nilai 0. Dalam penelitian ini digunakan analisis regresi logistik. Adapun model regresi logistik yang terbentuk adalah :

$$
\operatorname{Ln} \frac{\mathrm{p}}{1-\mathrm{p}}=\mathrm{b} 0+\mathrm{b} 1 \mathrm{x} 1+\mathrm{b} 2 \times 2+\mathrm{b} 3 \times 3+\mathrm{b} 4 \times 4+\mathrm{b} 5 \times 5+\mathrm{e}
$$

(Ghozali, 2016:324)

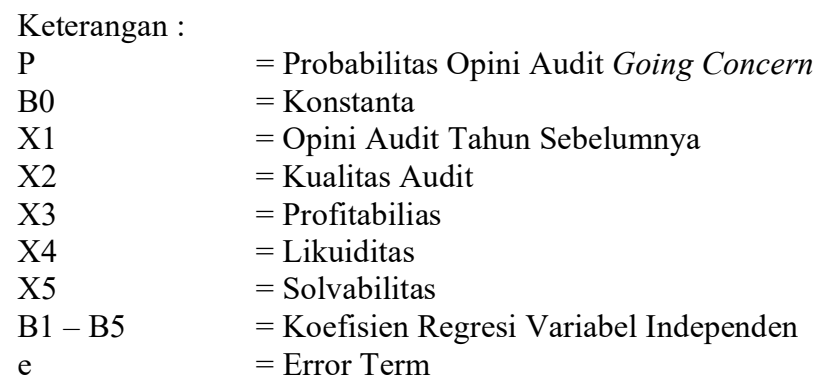




\section{Pengujian terhadap hipotesis dalam penelitian ini dilakukan dengan tahapan sebagai berikut :}

a. Menilai Model Fit dan Keseluruhan Model (Overall Model Fit)

Langkah pertama adalah menilai overall fit model terhadap data. Hipotesis untuk menilai model fit adalah sebagai berikut:

H0: Model yang dihipotesiskan fit dengan data

HA: Model yang dihipotesiskan tidak fit dengan data

Dari hipotesis ini jelas bahwa kita tidak akan menolak hipotesa nol agar supaya model fit dengan data. Statistik yang digunakan berdasarkan pada fungsi Likelihood. Likelihood (L) dari model adalah probabilitas bahwa model yang dihipotesiskan menggambarkan data input. Untuk menguji hipotesis nol dan hipotesis alternatif, L ditransformasikan menjadi -2LogL. Dengan degree of freedom n-q, dimana q adalah jumlah parameter dalam model, output SPSS memberikan dua nilai -2LogL, yaitu satu untuk model yang hanya memasukkan konstanta dan yang kedua untuk model dengan konstanta dan variabel bebas (Ghozali, 2016:328). Dengan $\alpha 5 \%$, cara menilai model fit ini adalah sebagai berikut :

1. Jika nilai $-2 \operatorname{LogL}<0,05$ maka $\mathrm{H} 0$ ditolak dan Ha diterima, yang berarti bahwa model tidak fit dengan data.

2. Jika nilai -2LogL $>0,05$ maka $\mathrm{H} 0$ diterima dan Ha ditolak, yang berarti bahwa model fit dengan data.

\section{b. Menilai Kelayakan Model Regresi}

Hipotesis untuk menilai kelayakan model regresi dengan uji ini adalah sebagai berikut :

1. Jika $\mathrm{H} 0<0,05$ maka $\mathrm{H} 0$ ditolak, yang berarti model tidak dapat memprediksi nilai observasinya.

2. Jika $\mathrm{HO}>0,05$ maka $\mathrm{H} 0$ diterima, yang berarti model dapat memprediksi nilai observasinya.

\section{c. Koefisien Determinasi}

Koefisien determinasi digunakan untuk mengetahui kemampuan variabel-variabel independen dalam menjelaskan variasi variabel dependen yang terbatas. Cox and Snell's $\mathrm{R}$ Square merupakan ukuran yang mencoba meniru ukuran $R^{2}$ pada multiple regression yang didasarkan pada teknik estimasi likelihood dengan nilai maksimum kurang dari 1 (satu) sehingga sulit diinterpretasikan. Negelkerke's R square merupakan modifikasi dari koefisien Cox dan Snell untuk memastikan bahwa nilainya bervariasi dari 0 (nol) sampai 1 (satu). Hal ini dilakukan dengan cara membagi nilai Cox dan Snell's $R^{2}$ dengan nilai maksimumnya. Nilai Nagelkerke"s $R^{2}$ dapat diinterpretasikan seperti nilai $R^{2}$ pada multiple regression (Ghozali, 2016:329).

\section{d. Omnimbus Test}

Test ini dilakukan untuk mengetahui apakah secara bersama-sama variabel bebas (independen) berpengaruh signifikan terhadap variabel tidak bebas (dependen) atau minimal ada satu variabel bebas yang berpengaruh signifikan terhadap variabel tak bebas. Uji ini mirip dengan uji $\mathrm{F}$ pada analisis regresi linier berganda. Nilai uji ini dapat dilihat menggunakan nilai p-value kemudian dibandingkan dengan nilai $\alpha$, dengan kriteria sebagai berikut: 
1. Jika $p$-value lebih besar daripada $\alpha(0,05)$ maka variabel-variabel independen tidak berpengaruh secara bersama-sama (stimultan) pada pergantian auditor independen atau $\mathrm{H}_{0}$ diterima.

2. Jika $p$-value lebih kecil daripada $\alpha(0,05)$ maka variabel-variabel independen berpengaruh secara bersama-sama (stimultan) pada pergantian auditor independen atau $\mathrm{H}_{0}$ ditolak.

\section{Pengujian Hipotesis}

Hipotesis dalam penelitian ini yaitu Opini audit tahun sebelumnya, Kualitas Audit, Profitabilitas, Likuiditas, Solvabilitas, dan Going Concern. Tahapan dalam pengujian dengan menggunakan uji regresi logistik (logistic regression), Estimasi parameter menggunakan Maximum Likehood Estimation (MLE) (Ghozali, 2016:330).

$$
\begin{aligned}
& \text { Ho }=\mathbf{b} 1=\mathbf{b} 2=b 3=. . .=b i=0 \\
& \text { Ho } \neq \mathbf{b} 1 \neq \mathbf{b} 2 \neq \mathbf{b 3} \neq \ldots \neq . . . b i \neq 0
\end{aligned}
$$

Hipotesis nol menyatakan bahwa variabel independen $(\mathrm{X})$ tidak mempunyai pengaruh terhadap variabel respon yang diperhatikan (dalam populasi). Pengujian terhadap hipotesis dilakukan dengan menggunakan $\alpha=5 \%$.

Kaidah pengambilan keputusan adalah :

1. Jika nilai probabilitas (sig) $>0,05$ maka H0 diterima, yang berarti bahwa variabel independen tidak berpengaruh secara signifikan terhadap variabel dependen.

2. Jika nilai probabilitas (sig) $<0,05$ maka H0 ditolak, yang berarti bahwa variabel independen berpengaruh signifikan terhadap variabel dependen.

\section{ANALISIS HASIL DAN PEMBAHASAN}

\section{Analisis Statistik Deskriptif}

Analisis deskriptif dalam penelitian ini disajikan untuk memberikan informasi mengenai karakteristik variabel-variabel penelitian. Tujuan dari statistika deskriptif adalah untuk mempelajari cara-cara pengumpulan, penyusunan, penyajian data, dan menarik kesimpulan suatu penelitian secara numerik. Berdasarkan hasil pengolahan data menggunakan IBM SPSS Statistic 23 dapat dilihat nilai minimum, maximum, mean, dan standar deviasi pada tabel sebagai berikut:

Tabel

\begin{tabular}{|c|c|c|c|c|c|}
\hline & $\mathrm{N}$ & Minimum & $\begin{array}{l}\text { Maximu } \\
\mathrm{m}\end{array}$ & Mean & $\begin{array}{l}\text { Std. } \\
\text { Deviation }\end{array}$ \\
\hline OATS & 160 & 0 & 1 &, 27 & ,445 \\
\hline KA & 160 & 0 & 1 &, 37 & ,486 \\
\hline ROA & 160 &,- 346 & ,331 &,- 01849 & ,079381 \\
\hline CR & 160 &, 130 & 11,492 & 1,41387 & 1,338878 \\
\hline TDTA & 160 &, 040 & 4,980 & ,91195 & ,834528 \\
\hline GCAO (Y) & 160 & 0 & 1 & ,26 & ,441 \\
\hline $\begin{array}{ll}\text { Valid } & \mathrm{N} \\
\text { (listwise) } & \end{array}$ & 160 & & & & \\
\hline
\end{tabular}

Statistik Deskriptif 


\section{Hasil Pengujian Model}

Karena variabel dependen bersifat dikotomi (menerima opini audit going concern dan menerima opini audit non going concern), maka pengujian terhadap hipotesis dilakukan dengan menggunakan uji regresi logistik. Hasil uji regresi logistik dapat dijelaskan sebagai berikut:

\section{Menilai Keseluruhan Model Fit}

Pengujian dilakukan dengan cara membandingkan nilai antara -2 log likehood (-2LL) awal (Block Number $=0$ ) dengan nilai -2 log likehood (-2LL) akhir (Block Number $=1)$. Jika dalam pengujian dihasilkan ada penurunan nilai antara -2LL awal dengan nilai -2LL pada akhir test (Block Number $=1$ ), maka menunjukkan bahwa model yang dihipotesiskan fit dengan data. Penurunan pada nilai Log Likehood menunjukkan bahwa model regresi semakin baik. Hasil uji model fit dapat dilihat pada tabel berikut:

\section{Tabel}

Overall Model Fit (Blok 0 : Beginning Block)

Iteration History $\mathbf{a}, \mathrm{b}, \mathrm{c}$

\begin{tabular}{|ll|l|l|}
\hline \multirow{2}{*}{ Iteration } & \multirow{2}{*}{ Step Log likelihood } & Coefficients \\
\cline { 4 - 4 } & 1 & 184,426 & Constant \\
\hline \multirow{2}{*}{ Step } & 2 & 184,210 &,- 950 \\
& 3 & 184,210 & $-1,031$ \\
& 4 & 184,210 & $-1,033$ \\
\hline
\end{tabular}

Tabel diatas adalah Iteration History (Block 0) yang merupakan -2 Log likelihood awal yaitu sebesar 184,210. Nilai yang tertera dalam tabel digunakan untuk dibandingkan dengan nilai pada Iteration History (Block 1) yang merupakan -2 Log likelihood akhir. Adanya pengurangan antara -2 Log likelihood awal dengan -2 Log likelihood akhir menunjukkan bahwa model yang dihipotesiskan fit dengan data.

Tabel

Overall Model Fit (Block 1 : Method = Enter) Iteration History $\mathbf{a}, \mathbf{b}, \mathbf{c}, \mathbf{d}$

\begin{tabular}{|c|c|c|c|c|c|c|c|}
\hline \multirow[b]{2}{*}{ Iteration } & \multirow{2}{*}{$\begin{array}{l}-2 \text { Log } \\
\text { likelihoo } \\
\text { d }\end{array}$} & \multicolumn{6}{|c|}{ Coefficients } \\
\hline & & Constant & OATS & KA & ROA & CR & TDTA \\
\hline Step 11 & 71,818 & $-1,862$ & 3,363 &,- 138 & $-1,142$ &,- 008 &, 054 \\
\hline 2 & 55,438 & $-2,723$ & 4,586 &,- 372 & $-3,023$ &,- 024 & , 129 \\
\hline 3 & 52,213 & $-3,226$ & 5,110 &,- 691 & $-5,424$ &,- 052 & 207 \\
\hline 4 & 51,853 & $-3,432$ & 5,318 &,- 879 & $-6,748$ &,- 073 & ,248 \\
\hline 5 & 51,846 & $-3,467$ & 5,356 &,- 911 & $-6,970$ &,- 077 & ,256 \\
\hline 6 & 51,846 & $-3,468$ & 5,357 &,- 911 & $-6,975$ &,- 077 & ,256 \\
\hline 7 & 51,846 & $-3,468$ & 5,357 &,- 911 & $-6,975$ &,- 077 & .256 \\
\hline
\end{tabular}


Setelah dimasukkan lima variabel independen, pada tabel diatas menunjukkan bahwa nilai -2 Log likelihood akhir (Block 1) adalah sebesar 51,846. Hal ini berarti -2 Log likelihood mengalami penurunan dari nilai awal pada nilai akhir yaitu sebesar 132,364. Penurunan nilai ini menunjukkan bahwa penambahan variabel bebas kedalam model dapat memperbaiki model fit serta menunjukkan model regresi yang lebih baik, dengan kata model yang dihipotesiskan fit dengan data.

\section{Menilai Kelayakan Model Regresi (Hosmer and Lemeshow's Goodness of Fit Test)}

Kelayakan model regresi dinilai dengan menggunakan Hosmer and Lemeshow's Goodness of Fit Test dengan kriteria sebagai berikut:

a. Jika $\mathrm{H} 0<0,05$ maka $\mathrm{H} 0$ ditolak, yang berarti model tidak dapat memprediksi nilai observasinya.

b. Jika $\mathrm{H} 0>0,05$ maka $\mathrm{H} 0$ diterima, yang berarti model dapat memprediksi nilai observasinya.

Hasil Hosmer and Lomeshow's Goodness of Fit Test dapat dilihat pada tabel berikut:

Tabel

Uji Kelayakan Model Regresi

\section{Hosmer and Lemeshow Test}

\begin{tabular}{|l|l|l|l|}
\hline Step & Chi-square & df & Sig. \\
\hline 1 & 6,232 & 8 &, 621 \\
\hline
\end{tabular}

Hasil pengujian stastistik menunjukkan chi-square 6,232 dengan nilai signifikasi 0,621 > 0,05, maka H0 diterima. Hal ini berarti tidak ada perbedaan antara model dengan data. Dengan demikian dapat disimpulkan bahwa model mampu memprediksi nilai observasi atau dapat dikatakan model fit dan dapat diterima karena cocok dengan data observasinya.

\section{Koefisien Determinasi}

Model summary bertujuan untuk mengetahui seberapa besar kombinasi variabel independen yaitu Opini Audit Tahun Sebelumnya, Kualitas Auditor, Profitabilitas, Likuiditas, dan Solvabilitas mampu menjelaskan variabel dependen yaitu Pemberian Opini Audit Going Concern. Hasil uji dari Nagelkerke R Square dapat dilihat pada tabel berikut:

Tabel

Hasil Uji Koefisien Determinasi

Model Summary

\begin{tabular}{|l|l|l|l|}
\hline Step & $\begin{array}{l}-2 \\
\text { likelihood Log }\end{array}$ & $\begin{array}{l}\text { Cox \& Snell R } \\
\text { Square }\end{array}$ & $\begin{array}{l}\text { Nagelkerke R } \\
\text { Square }\end{array}$ \\
\hline 1 & $51,846^{\mathrm{a}}$ &, 563 &, 823 \\
\hline
\end{tabular}


Tabel diatas menunjukkan nilai Negelkerke's $R$ square adalah sebesar 0,823 yang berarti validitas dependen yang dapat dijelaskan oleh variabel independen adalah sebesar $82,3 \%$, dan sisanya $17,7 \%$ dijelaskan oleh variabel-variabel lain diluar model penelitian.

\section{Uji Omnibus (Overall Test)}

Test ini dilakukan untuk mengetahui apakah secara bersama-sama variabel bebas (independen) berpengaruh signifikan terhadap variabel tidak bebas (dependen) atau minimal ada satu variabel bebas yang berpengaruh signifikan terhadap variabel tak bebas. Uji ini mirip dengan uji $\mathrm{F}$ pada analisis regresi linier berganda. Nilai uji ini dapat dilihat menggunakan nilai p-value kemudian dibandingkan dengan nilai $\alpha$, dengan kriteria sebagai berikut:

a. Jika $p$-value lebih besar daripada $\alpha(0,05)$ maka variabel-variabel independen tidak berpengaruh secara bersama-sama (stimultan) pada pemberian opini going concern atau $\mathrm{H}_{0}$ diterima.

b. Jika p-value lebih kecil daripada $\alpha(0,05)$ maka variabel-variabel independen berpengaruh secara bersama-sama (stimultan) pada pemberian opini going concern atau $\mathrm{H}_{0}$ ditolak.

\section{Tabel}

Hasil Pengujian secara Simultan Omnibus Tests of Model Coefficients

\begin{tabular}{|ll|l|l|l|}
\hline & & Chi-square & df & Sig. \\
\hline Step 1 & Step & 132,364 & 5 &, 000 \\
& Block & 132,364 & 5 &, 000 \\
& Model & 132,364 & 5 &, 000 \\
\hline
\end{tabular}

Berdasarkan tabel diatas menunjukkan bahwa p-value sebesar 0,000 . Nilai p-value ini lebih rendah dari tingkat signifikansi uji $(\alpha)$ sebesar 0.05 sehingga $\mathrm{H}_{0}$ ditolak. Ini berarti bahwa opini audit tahun sebelumnya, kualitas auditor, profitabilitas, likuiditas, dan solvabilitas secara simultan atau bersama-sama berpengaruh terhadap pemberian opini audit going concern.

\section{Pengujian Hipotesis}

Pengujian hipotesis dalam penelitian ini untuk menguji perngaruh variabel-variabel bebas yaitu opini audit tahun sebelumnya, kualitas auditor, profitabilitas, likuiditas dan solvabilitas terhadap pemberian opini going concern. Pengujian dilakukan dengan menggunakan hasil uji regresi logistik yang ditunjukkan dalam variables in the equation pada kolom significant yang dibandingkan dengan tingkat kealphaan 5\%. Apabila tingkat signifikasinya $<0.05$, maka Ha diterima. 
Tabel

Koefisien Regresi Model

Variables in the Equation

\begin{tabular}{|ll|l|l|l|l|l|l|}
\hline & B & S.E. & Wald & df & Sig. & Exp(B) \\
\hline Step & OATS & 5,357 &, 845 & 40,163 & 1 &, 000 & 212,047 \\
$1^{\text {a }}$ & KA &,- 911 &, 938 &, 943 & 1 &, 331 &, 402 \\
& ROA & $-6,975$ & 5,760 & 1,467 & 1 &, 226 &, 001 \\
CR &,- 077 &, 261 &, 087 & 1 &, 768 &, 926 \\
& TDTA &, 256 &, 469 &, 299 & 1 &, 585 & 1,292 \\
Constant & $-3,468$ &, 819 & 17,909 & 1 &, 000 &, 031 \\
\hline
\end{tabular}

a. Variable(s) entered on step 1: OATS, KA, ROA, CR, TDTA.

Tabel menunjukkan hasil uji regresi logistik pada tingkat signifikasi ( $\alpha$ ) 5\%. Dari pengujian persamaan regresi logistik diatas, maka diperoleh persamaan regresi sebagai berikut:

$$
\operatorname{Ln} \frac{G C A O}{1-G C A O}=-3.468+5.357 \mathrm{OATS}-0.911 \mathrm{KA}-6.975 \mathrm{ROA}-0.077 \mathrm{CR}+0.256+\mathrm{e}
$$

Dari persamaan regresi diatas maka dapat dianalisis sebagai berikut:

1. Konstanta sebesar -3,468 menyatakan bahwa jika tidak diperhitungkan Opini Audit Tahun Sebelumnya, Kualitas Auditor, Profitabilitas, Likuiditas, dan Solvabilitas, maka kemungkinan penerimaan opini audit going concern adalah sebesar -3,468.

2. Hasil pengujian hipotesis menunjukkan variabel opini audit tahun sebelumnya memiliki koefisien regresi positif sebesar 5,357 dengan tingkat signifikasi 0,000 yang lebih kecil dari $\alpha(5 \%)$. Koefisien positif menunjukkan setiap peningkatan opini audit tahun sebelumnya (OATS) sebesar satu poin, membuat kecenderungan mengalami peningkatan atas penerimaan opini audit going concern sebesar 5,357.

3. Hasil pengujian hipotesis kedua menunjukkan kualitas auditor yang dilihat dari KAP yang termasuk Big Four memiliki koefisien regresi sebesar -0.911 dengan tingkat signifikasi 0,331 yang lebih besar dari $\alpha(5 \%)$. Koefisien negatif menunjukkan setiap peningkatan kualitas auditor (KA) sebesar satu poin, membuat kecenderungan mengalami penurunan atas penerimaan opini audit going concern sebesar 0,911 .

4. Hasil pengujian hipotesis ketiga menunjukkan profitabilitas yang dilihat dari $R O A$ yaitu laba bersih setelah pajak dibagi dengan total asset memiliki koefisien regresi sebesar 6,975 dengan tingkat signifikasi 0,226 yang lebih besar dari $\alpha(5 \%)$. Koefisien negatif menunjukkan setiap peningkatan profitabilitas (ROA) sebesar satu poin, membuat kecenderungan mengalami penurunan atas penerimaan opini audit going concern sebesar 6,975 .

5. Hasil pengujian hipotesis keempat menunjukkan likuiditas yang dilihat dari Current Assets yaitu asset lancar dibagi dengan kewajiban lancar, memiliki koefisien regresi sebesar 0,077 dengan tingkat signifikasi 0,768 yang lebih besar dari $\alpha(5 \%)$. Koefisien negatif menunjukkan setiap peningkatan likuiditas (CR) sebesar satu poin, membuat kecenderungan mengalami penurunan atas penerimaan opini audit going concern sebesar 0,077 . 
6. Hasil pengujian hipotesis kelima menunjukkan solvabilitas yang dilihat dari TDTA yaitu total kewajiban dibagi dengan total asset memiliki koefisien regresi positif sebesar 0,256 dengan tingkat signifikasi 0,585 yang lebih besar dari $\alpha(5 \%)$. Koefisien positif menunjukkan setiap peningkatan solvabilitas (TDTA) sebesar satu poin, membuat kecenderungan mengalami peningkatan atas penerimaan opini audit going concern sebesar 0,077 .

7. Hipotesis keenam, yaitu menguji semua variabel independen yaitu opini audit tahun sebelumnya, kualitas auditor, profitabilitas, likuiditas, dan solvabilitas yang diuji secara bersama-sama dengan menggunakan Omnibus Test of Model Coefficient bertujuan untuk melihat apakah kelima variabel tersebut secara bersama-sama berpengaruh dalam pemberian opini audit going concern. Hasil pengujian secara simultan dilihat dari Omnibus Test of Model Coefficient. yang menunjukkan variabel independen berpengaruh dalam pemberian opini audit going concern.

\section{Pembahasan dan Interpretasi Penelitian}

\section{Pengaruh Opini Audit Tahun Sebelumnya terhadap Pemberian Opini Going Concern}

$\mathrm{Ha}_{1}$ : ada pengaruh opini audit tahun sebelumnya terhadap pemberian opini going concern.

Opini audit tahun sebelumnya yang menggunakan variabel dummy menunjukkan koefisien 5,357 dan tingkat signifikan sebesar 0,000. Hal ini berarti tingkat signifikansinya lebih kecil dari $\alpha$, yaitu $0,000<0,05$ dan kesimpulannya $\mathrm{Ha}_{1}$ diterima, artinya dapat disimpulkan bahwa opini audit going concern tahun sebelumnya berpengaruh signifikan terhadap pemberian opini audit going concern.

Jika perusahaan mendapatkan opini audit going concern ditahun sebelumnya, maka hal ini akan menjadi faktor yang dipertimbangkan auditor dan menjadi bahan evaluasi untuk memberikan opini going concern ditahun selanjutnya. Sehingga besar kemungkinan untuk menerima opini audit going concern lagi pada tahun sekarang.

Hasil penelitian ini selaras dengan penelitian yang dilakukan oleh Soliyah (2014) yang menunjukkan bahwa opini audit tahun sebelumnya berpengaruh terhadap pemberian opini going concern. Begitu pula dengan penelitian yang dilakukan oleh Herry dan Nur (2013) yang menemukan hubungan kuat antara opini audit tahun sebelumnya dengan penerimaan opini audit going concern.

\section{Pengaruh Kualitas Auditor terhadap Pemberian Opini Going Concern}

$\mathrm{Ha}_{2}$ : ada pengaruh kualitas auditor terhadap pemberian opini going concern.

Kualitas auditor yang menggunakan variabel dumm menunjukkan koefisien -0,911 dan tingkat signifikan sebesar 0,331 . Hal ini berarti tingkat signifikansinya lebih besar dari $\alpha$, yaitu 0,331 >0,05 dan kesimpulannya $\mathrm{Ha}_{2}$ ditolak. Dengan demikian, kualitas auditor tidak berpengaruh terhadap pemberian opini audit going concern. Hal ini berarti bahwa kantor akuntan publik yang termasuk dalam Big Four maupun Non Big Four sama-sama memberikan kualitas audit yang baik dan bersikap independen dalam mengeluarkan opini audit going concern. Kantor akuntan publik yang baik akan berusaha untuk mempertahankan reputasinya dan menghindar dari hal-hal yang bisa merusak reputasi tersebut, sehingga akan selalu bersikap objektif terhadap pekerjaannya. Jika mereka menemukan adanya masalah 
pada auditee yang mengancam kelangsungan hidup auditee tersebut, maka opini uang akan diberikan adalah opini going concern.

Hasil penelitian ini selaras dengan penelitian yang dilakukan oleh Friska (2015) yang menunjukkan bahwa kualitas auditor tidak berpengaruh terhadap pemberian opini going concern. Serta penelitian Aiisiah dan Pamudji (2013) yang menyatakan bahwa kualitas auditor tidak berpengaruh terhadap kemungkinan pemberian opini going concern.

\section{Pengaruh Profitabilitas terhadap Pemberian Opini Going Concern}

$\mathrm{Ha}_{3}$ : ada pengaruh profitabilitas terhadap pemberian opini going concern.

Profitabilitas yang diproksikan dengan ROA pada tabel menunjukkan koefisien sebesar 6,975 dan tingkat signifikan sebesar 0,226. Hal ini berarti tingkat signifikansinya lebih besar dari $\alpha$, yaitu $0,226>0,05$. Maka dapat disimpulkan bahwa $\mathrm{Ha}_{3}$ ditolak, yang artinya rasio profitabilitas tidak berpengaruh terhadap pemberian opini going concern. Rasio profitabilitas tidak dapat digunakan sebagai pengukuran untuk menentukan apakah perusahaan mendapatkan opini audit dengan paragraf going concern atau tidak.

Meningkatnya laba usaha tidak selalu diimbangi dengan menurunnya hutang perusahaan. Jika perusahaan ingin melakukan produksi yang lebih banyak, perusahaan juga akan memerlukan dana yang lebih besar, dimana perusahaan akan mendapatkannya melalui hutang perusahaan. Jadi bila perusahaan tidak dapat melunasi hutang tersebut, perusahaan juga tetap akan bisa mendapatkan opini audit dengan paragraf going concern.

Profitabilitas yang tinggi tidak selalu mencerminkan baiknya kinerja perusahaan, jika profitabilitas yang tinggi tidak disertai dengan penekanan biaya yang akan menyebabkan profit perusahaan kurang maksimal. Jadi, selain meningkatkan profitabilitas perusahaan, perusahaan juga harus meningkatkan efisiensi penggunaan biaya dan meningkatkan produktifitas kerja.

Hasil penelitian ini selaras dengan penelitian yang dilakukan oleh Soliyah (2014) seta Herry dan Nur (2013) yang menyatakan bahwa profitabilitas tidak berpengaruh terhadap pemberian opini going concern.

\section{Pengaruh Likuiditas terhadap Pemberian Opini Going Concern}

$\mathrm{Ha}_{4}$ : ada pengaruh likuiditas terhadap pemberian opini going concern.

Likuiditas yang diproksikan dengan Current Ratio pada tabel menunjukkan koefisien regresi sebesar -0,077, dan tingkat signifikan sebesar 0,768. Hal ini berarti tingkat signifikansinya lebih besar dari $\alpha, 0,768>0,05$. Maka dapat disimpulkan bahwa Ha4 ditolak, yang artinya rasio likuiditas tidak berpengaruh terhadap pemberian opini going concern. Hal ini dapat diartikan bahwa semakin baik posisi keuangan perusahaan, maka semakin rendah pula opini audit non going concern yang dikeluarkan oleh auditor

Penelitian ini memberikan bukti empiris bahwa perusahaan yang memiliki kondisi keuangan (likuiditas) tidak sehatpun bisa memiliki opini non going concern. Likuiditas merupakan kemampuan perusahan dalam melunasi utang jangka pendeknya. Kemampuan perusahaan dalam mempertahankan kelangsungan hidup perusahaan tidak hanya dilihat dari likuiditas saja. Perusahaan dapat memiliki potensi lain dalam mempertahankan kelangsungan hidupnya, seperti mendapat pasokan modal baru atau memilki kemampuan dalam menghasilkan laba yang baik pada tahun selanjutnya. 
Hasil penelitian ini selaras dengan penelitian yang dilakukan Herry dan Nur (2013) serta Noverio (2011) yang menunjukkan bahwa likuiditas tidak berpengaruh terhadap pemberian opini going concern.

\section{Pengaruh Solvabilitas terhadap Pemberian Opini Going Concern}

$\mathrm{Ha}_{5}$ : ada pengaruh solvabilitas terhadap pemberian opini going concern.

Solvabilitas yang diproksikan dengan TDTA pada tabel menunjukkan koefisien regresi positif sebesar 0,256 dengan tingkat signifikasi 0,585 . Hal ini berarti tingkat signifikansinya $>0.05$. Maka dapat disimpulkan bahwa $\mathrm{Ha}_{5}$ ditolak, yang artinya rasio solvabilitas tidak berpengaruh terhadap pemberian opini going concern. Rasio solvabilitas tidak mempengaruhi auditor untuk memberikan opini audit dengan paragraf going concern. Kondisi ini terjadi karena perusahan dengan solvabilitas yang tinggi, akan tetapi memiliki perencanaan dalam memperbaiki operasi perusahaan dan kemampuan untuk mengelola keuangan dengan baik, serta mampu menyajikan laporan keuangan yang wajar, maka tidak akan mendapatkan opini audit going concern.

Hasil penelitian ini selaras dengan penelitian yang dilakukan oleh Ayu dan Caecilia (2011) yang membuktikan secara empiris bahwa rasio solvabilitas tidak berpengaruh terhadap pemberian opini audit going concern.

\section{Pengaruh Opini Audit Tahun Sebelumnya, Kualitas Auditor, Profitabilitas, Likuiditas dan Solvabilitas terhadap Pemberian Opini Going Concern}

$\mathrm{Ha}_{6}$ : ada pengaruh opini audit tahun sebelumnya, kualitas auditor, profitabiltas, likuiditas dan solvabilitas terhadap pemberian opini going concern.

Hasil pengujian untuk hipotesis keenam adalah untuk melihat hubungan opini audit tahun sebelumnya, kualitas auditor, profitabiltas, likuiditas dan solvabilitas secara bersamasama atau simultan terhadap pemberian opini going concern. Pada tabel diatas menunjukkan chi-square 132,364 dengan tingkat signifikasi sebesar $0,000<0,05$. Ini menujukkan bahwa $\mathrm{Ha}_{6}$ diterima, yang artinya opini audit tahun sebelumnya, kualitas auditor, profitabiltas, likuiditas dan solvabilitas secara bersama-sama atau simultan berpengaruh terhadap pemberian opini going concern.

\section{KESIMPULAN DAN SARAN}

\section{Kesimpulan}

Dari hasil yang diperoleh pada pembahasan diatas maka kesimpulan yang dapat diambil adalah:

1. Opini audit tahun sebelumnya berpengaruh positif secara signifikan terhadap pemberian opini audit going concern. Hal ini dapat dijelaskan dengan besaran tingkat signifikasi sebesar 0,000 .

2. Kualitas auditor tidak berpengaruh terhadap pemberian opini audit going concern. Hal ini dapat dijelaskan dengan besaran tingkat signifikasi sebesar 0,331 .

3. Profitabilitas tidak berpengaruh terhadap pemberian opini audit going concern. Hal ini dapat dijelaskan dengan besaran tingkat signifikasi sebesar 0,226. 
4. Likuiditas tidak berpengaruh terhadap pemberian opini audit going concern. Hal ini dapat dijelaskan dengan besaran tingkat signifikasi sebesar 0,768.

5. Solvabilitas tidak berpengaruh terhadap pemberian opini audit going concern. Hal ini dapat dijelaskan dengan besaran tingkat signifikasi sebesar 0,585.

6. Opini audit tahun sebelumnya, kualitas auditor, profitabilitas, likuiditas dan solvabilitas berpengaruh terhadap pemberian opini audit going concern. Hal ini dapat dijelaskan dengan besaran tingkat signifikasi sebesar 0,000 .

\section{Saran}

Berdasarkan kesimpulan diatas, maka diajukan saran sebagai berikut:

1. Peneliti selanjutnya sebaiknya menggunakan seluruh proksi keuangan dalam setiap variabel keuangan dalam menganaisa tingkat profitabilitas, likuiditas, dan solvabilitas agar dapat memberikan hasil yang relevan dan dapat digeneralisasi bagi berbagai jernis perusahaan sehingga penelitian dapat menjadi acuan bagi perusahaan jenis lainnya.

2. Peneliti selanjutnya sebaiknya menambah periode tahun pengamatan sehingga dapat memperoleh sampel yang lebih banyak serta untuk melihat trend negatif yang ada.

3. Peneliti selanjutnya sebaiknya menggunakan variabel-variabel lain diluar variabel dalam penelitian ini sebagai faktor yang mempengaruhi pemberian opini going concern.

4. Peneliti selanjutnya sebaiknya menggunakan jenis perusahaan yang bergerak dibidang selain manufaktur yang terdaftar di Bursa Efek Indonesia (BEI) untuk menguji apakah faktor-faktor yang mempengaruhi pemberian opini going concern ini juga berlaku unuk perusahaan di industri lain.

\section{DAFTAR PUSTAKA}

Ani Rahmaniar, Soegijanto. 2016. Pengantar Akuntansi Dasar I, In Media, Bogor.

Ayu Wilujeng Rahayu dan Caecilia Widi Pratiwi. 2011. Pengaruh Opini Au dit Tahun Sebelumya, Pertumbuhan Perusahaan, dan Reputasi Auditor terhadap Peneriman Opini Audit Going Concern. Jurnal Ekonomi. Fakultas Ekonomi Universitas Gunadarma.

Dian Elmawati, 2014. Pengaruh Reputasi KAP, Audit Tenure, dan Disclosure terhadap Penerimaan Opini Audit Going Concern. Jurnal Ekonomi. Fakultas Ekonomi Universitas Dipenogoro.

Friska Kristiani Sinurat, 2015. Analisis Pengaruh Likuiditas, Ukuran Perusahaan, dan Reputasi Audit terhadap Penerimaan Opini Audit Going Concern. Jurnal Fakultas Ekonomi Universitas Sanata Dharma.

Hery. 2015. Analisis Laporan Keuangan, CAPS, Yogyakarta.

Herry Sutanto dan Nur Mettani Aquariza, 2013. Analisis Pengaruh Opini Audit Tahun Sebelumnya, Kualitas Auditor, Profitabilitas, Likuiditas, dan Solvabilitas terhadap Pemberian Opini Audit Going Concern pada Perusahaan Consumer Goods Industry yang Terdaftar di Bursa Efek Indonesia. Jurnal Ekonomi. Fakultas Ekonomi Universitas Gunadarma.

Ikatan Akuntansi Indoesia. 2011. Standar Profesional Akuntan Publik, Salemba Empat, Jakarta.

Imam Ghozali. 2016. Aplikasi Analisis Multivariant dangan Program SPSS, Badan Penerbit Universitas Dipenogoro, Semarang.

Jensen, M. and Meckling, W. (1976), "Theory of the firm: Managerial Behaviour, agency costs and ownership structure", Journal of Financial Economics 3 (4), 305-360. 
Kasmir. 2015. Analisis Laporan Keuangan, Rajagrafindo Persada, Depok.

M. Mamduh Hanafi, Abdul Halim. 2012. Analisis Laporan Keuangan, UPP STIM YKPN, Jakarta.

Mulyadi. 2011. Auditing. Buku 1, Salemba Empat, Yogyakarta.

Nurul Aiisiah dan Sugeng Pamudji, 2012. Pengaruh Kualitas Audit, Kondisi Keuangan Perusahaan, Opini Audit Tahun Sebelumnya, Pertumbuhan Perusahaan dan Ukuran Perusahaan Terhadap Kecenderungan Penerimaan Opini Audit Going Concern. Jurnal Akuntansi Fakultas Ekonomika dan Bisnis Universitas Diponegoro.

Rezhky Noverio. 2011. Analisis Pengaruh Kualitas Auditor, Likuiditas, Profitabilitas, dan Solvablitas Terhadap opini Audit Going Concern pada Perusahaan Manufaktur yang Terdaftar di Bursa Efek Indonesia. Jurnal Ekonomi. Fakultas Ekonomi Universitas Dipenogoro.

Rizka Adhi Pradikha, 2017. Pengaruh Profitabilitas, Likuiditas, dan Ukuran Perusahaan Terhadap Opini Audit Going Concern. Jurnal Ekonomi. Fakultas Ekonomi Universitas Negeri Yogyakarta.

Santosa, Arga Fajar dan Linda Kusumaning Wedari. 2007. Analisis Faktor-Faktor yang mempengaruhi kecenderungan penerimaan Opini Audit Going Concern. JAAI Volume 11 No.2, Desember 2007.

Setyarno, E. B., Januarti, I., dan Faisal. 2006. Pengaruh Kualitas Audit, Kondisi Keuangan Perusahaan, Opini Audit Tahun Sebelumnya, Pertumbuhan Perusahaan terhadap Opini Audit Going Concern. Simposium Nasional Akuntansi IX Padang. IAI KAPd. Jakarta. Hal. 2-95.

Sofyan Syafri Harahap. 2010. Analisa Kritis Atas Laporan Keuangan, PT. Raja Grafindo Persada, Jakarta.

Soliyah Wulandari, 2014. Analisis Faktor-faktor Yang Mempengaruhi Auditor Dalam Memberikan Opini Audit Going Concern. E-Jurnal Akuntansi Universitas Udayana.

Sugiyono. 2011. Metode Penelitian Kuantitatif Kualitatif dan R\&D. Cetakan Ke-13, CV. Alfabeta, Bandung.

Sukrisno Agoes. 2012. Auditing: Petunjuk praktis Pemeriksaan Akuntan oleh Akuntan Publik, Salemba Empat, Jakarta.

Sutrisno. 2013. Manajemen Keuangan, Ekonisia, Yogyakarta.

Wiratna V. Sujarweni. 2017. Analisis Laporan Keuangan, Pustaka Baru Press, Yogyakarta.

Yunida, Riswan, dan Wardhana, M. Wahyu. 2013. Pengaruh Kualitas Audit, Kondisi Keuangan Perusahaan, Opini Audit Tahun Sebelumnya, Pertumbuhan Perusahaan Terhadap Opini Audit Going Concern. Jurnal INTEKNA, Tahun XIII, No. 1, 54 - 61. 